Supplement of Biogeosciences, 14, 5533-5549, 2017

https://doi.org/10.5194/bg-14-5533-2017-supplement

(C) Author(s) 2017. This work is distributed under

the Creative Commons Attribution 3.0 License.

(c) (1)

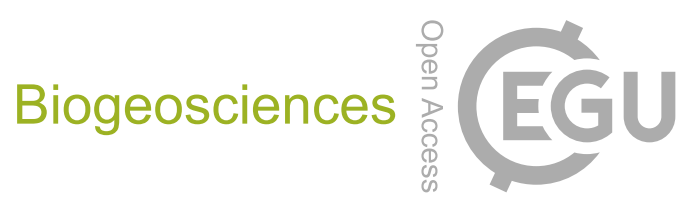

Supplement of

\title{
Exploring the contributions of vegetation and dune size to early dune development using unmanned aerial vehicle (UAV) imaging
}

Marinka E. B. van Puijenbroek et al.

Correspondence to: Marinka E. B. van Puijenbroek (marinka.vanpuijenbroek@gmail.com)

The copyright of individual parts of the supplement might differ from the CC BY 3.0 License. 


\section{SUPPORTING INFORMATION}

\section{Dunes from above: exploring the contributions of vegetation and dune size to early dune}

building

Marinka E.B. van Puijenbroek, Corjan Nolet, Alma V. de Groot, Juha Suomalainen, Michel J.P.M. Riksen, Frank Berendse and Juul Limpens

Supplement S1 Weather conditions

Fig. S1.1 The wind speed and direction for the years 2013 - 2016. The wind rose shows the percentage the wind came from a certain direction over the time-period 2013 - 2016. The colours show the wind speed in $\mathrm{m} \mathrm{s}^{-1}$.
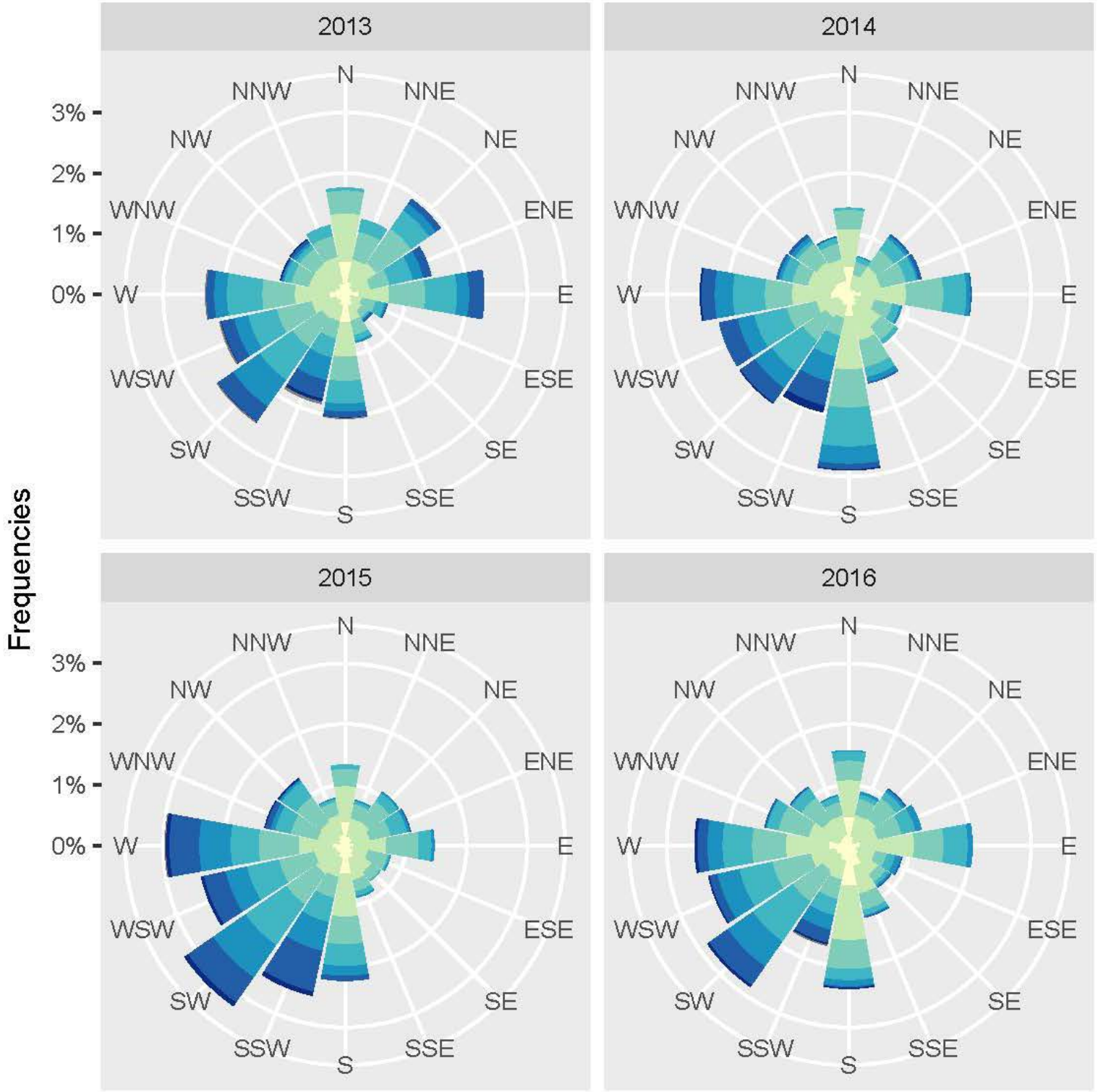

Wind Speed $(\mathrm{m} / \mathrm{s})$

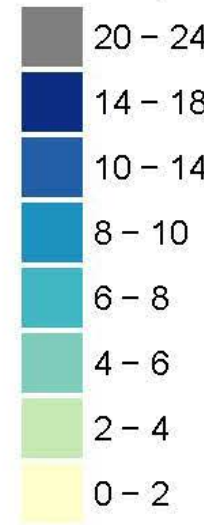

NA 
Table S1.1 Weather conditions in the years 2013 - 2016. For temperature the average is shown, and the precipitation was summed. For the precipitation in summer we summed the precipitation between the months April - August

\begin{tabular}{ccccc}
\hline Year & $\begin{array}{l}\text { Temp. June } \\
\text { \& July }\left({ }^{\circ} \mathbf{C}\right)\end{array}$ & $\begin{array}{l}\text { Temp. Januari \& } \\
\text { Februari }\left({ }^{\circ} \mathbf{C}\right)\end{array}$ & $\begin{array}{l}\text { Total } \\
\text { precipitation } \\
(\mathbf{m m})\end{array}$ & $\begin{array}{l}\text { Precipitation } \\
\text { Summer } \\
(\mathbf{m m})\end{array}$ \\
\hline 2013 & 15.67 & 2.25 & 553.2 & 163.1 \\
2014 & 17.40 & 5.96 & 714.8 & 360.6 \\
2015 & 15.98 & 4.47 & 804 & 283.8 \\
2016 & 16.38 & 4.90 & 708.2 & 275.9 \\
\hline
\end{tabular}

Table S1.2 Storm intensity in the years 2013 - 2016. The storm duration is calculated as the time the water level is above the water level recurrence of once a year.

\begin{tabular}{lcc}
\hline Year & $\begin{array}{l}\text { Storm } \\
\text { duration } \\
\text { (min) }\end{array}$ & $\begin{array}{l}\text { Maximum } \\
\text { water } \\
\text { level (cm) }\end{array}$ \\
\hline Winter 2013 - 2014 & 530 & 254 \\
Winter 2014 - 2015 & 410 & 248 \\
Winter 2015 - 2016 & 10 & 211 \\
\hline
\end{tabular}


Supplement S2 DTM, DSM and orthomosaic of each mapping campaign

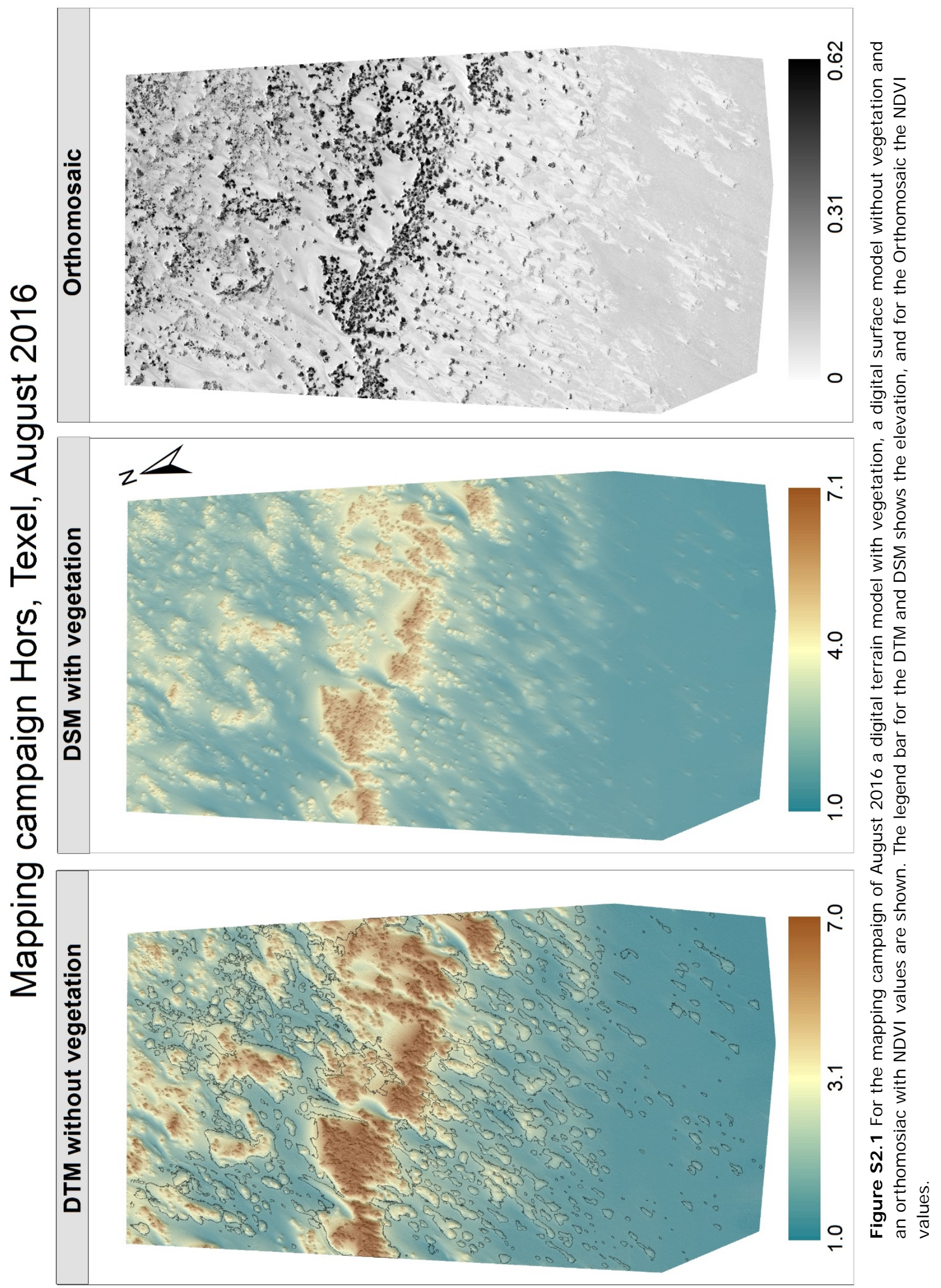




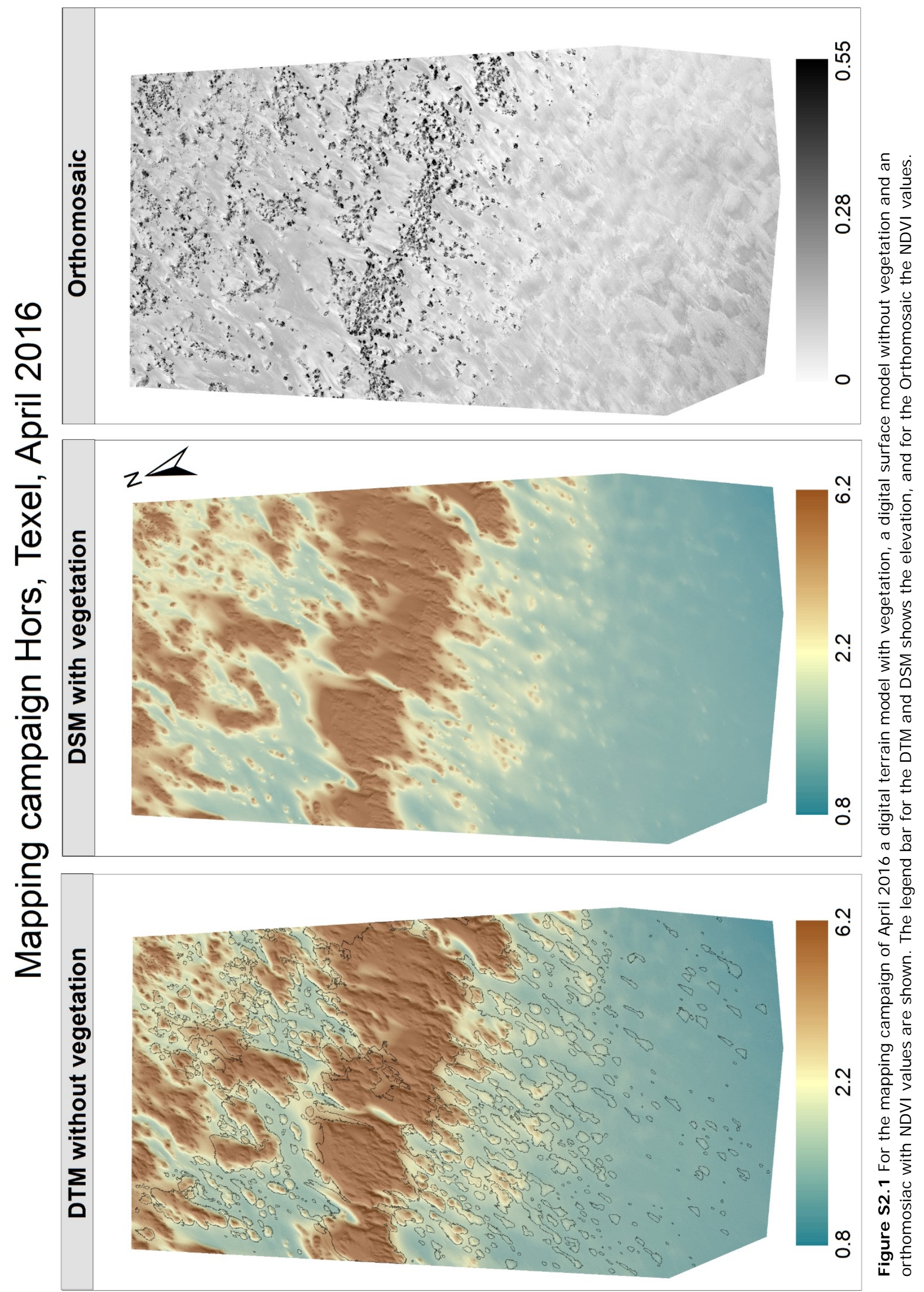




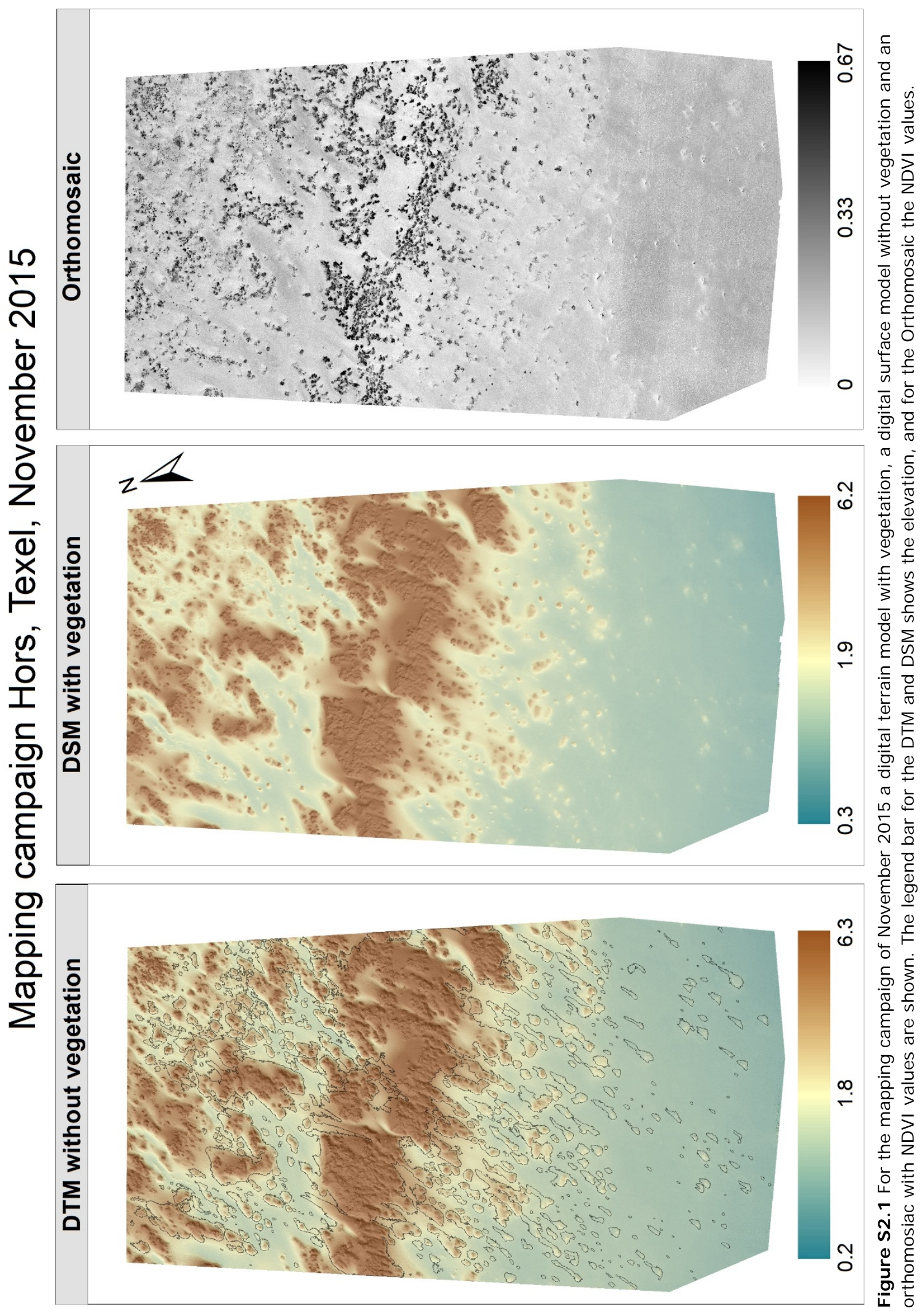


Supplement S3 Dune morphology selected dunes
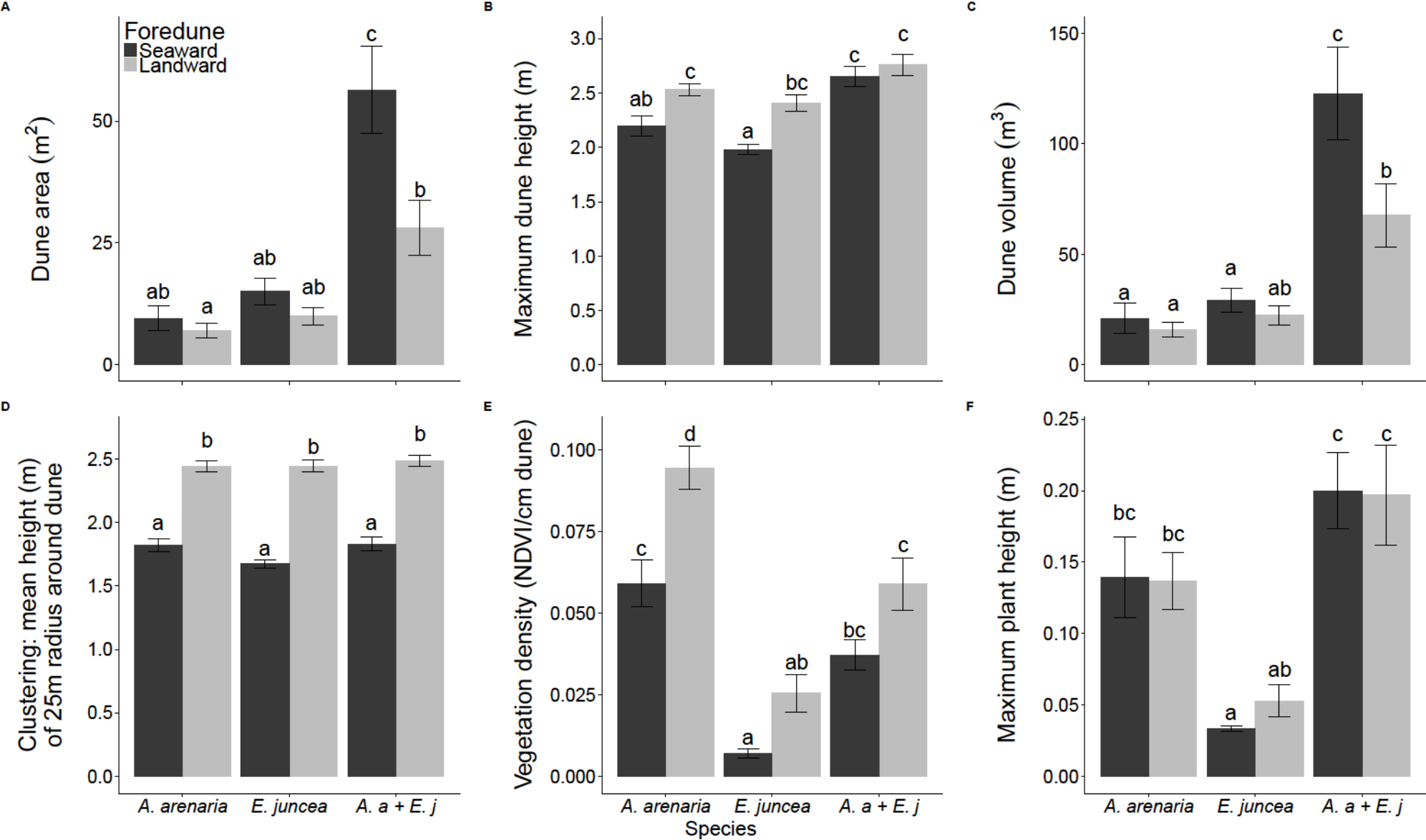

Fig. S3.1 Different dune characteristics for dunes with the blocks A. arenaria, E. juncea and a mix of both species separated for dune seaward and landward of the foredune: A) Dune area $\left.\left(\mathrm{m}^{2}\right), \mathrm{B}\right)$ Maximum dune height (m NAP), C) Dune volume $\left(\mathrm{m}^{3}\right)$, D) Clustering: mean height (m NAP) around a $25 \mathrm{~m}$ radius around the dune, E) Vegetation density (NDVI/cm), F) Plant height (m), The letters denote the significant difference between the bars. 
Supplement S4 Accuracy photogrammetric reconstruction

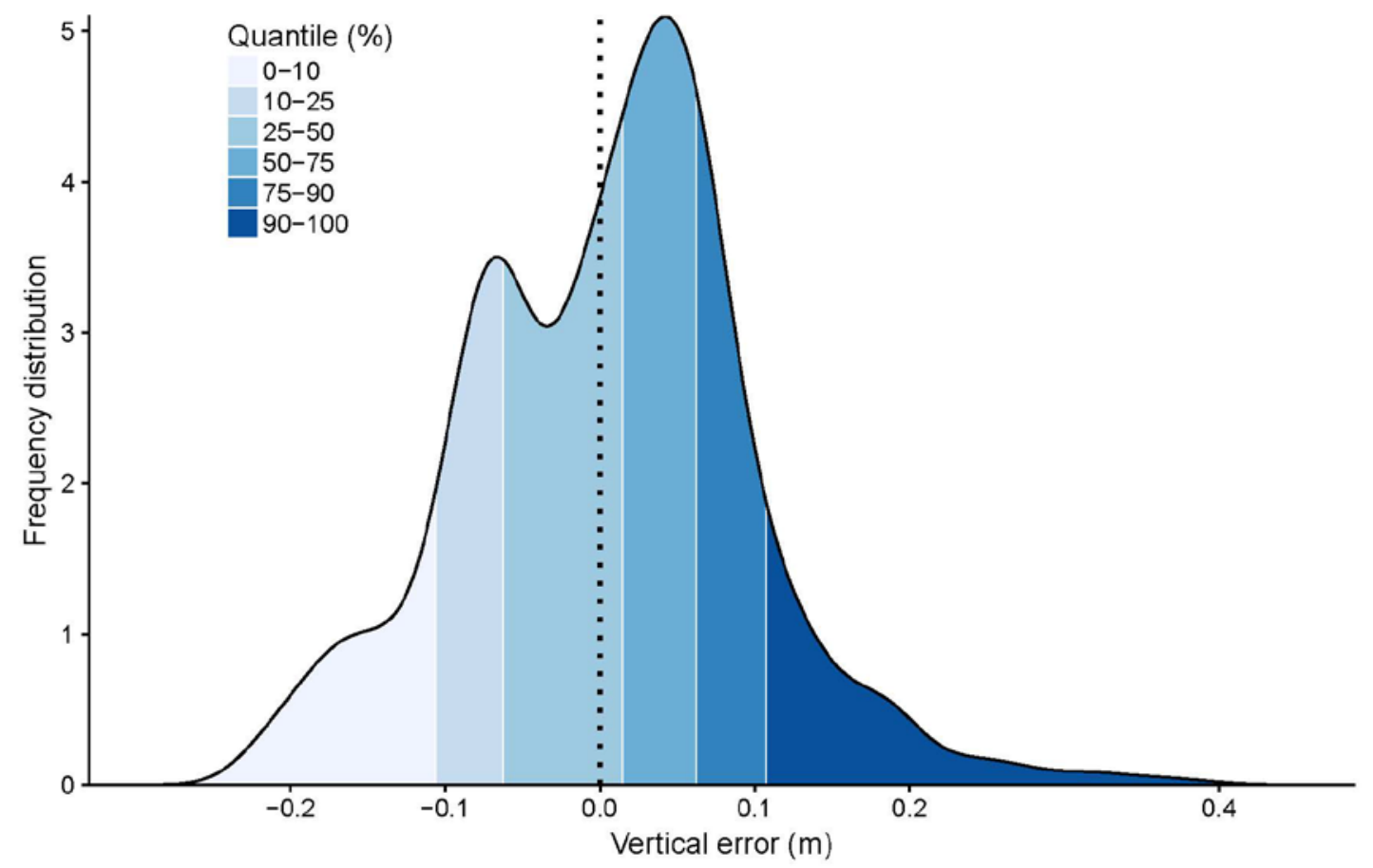

Figure S4.1 The frequency distribution of the vertical error (m) of the digital terrain model. The vertical error was calculated by subtracting the actual elevation measured with a RTKDGPS Trimble R6 Model 3 (TSC3) from the elevation of the digital terrain model (without vegetation). The colours indicate the quantile distribution.

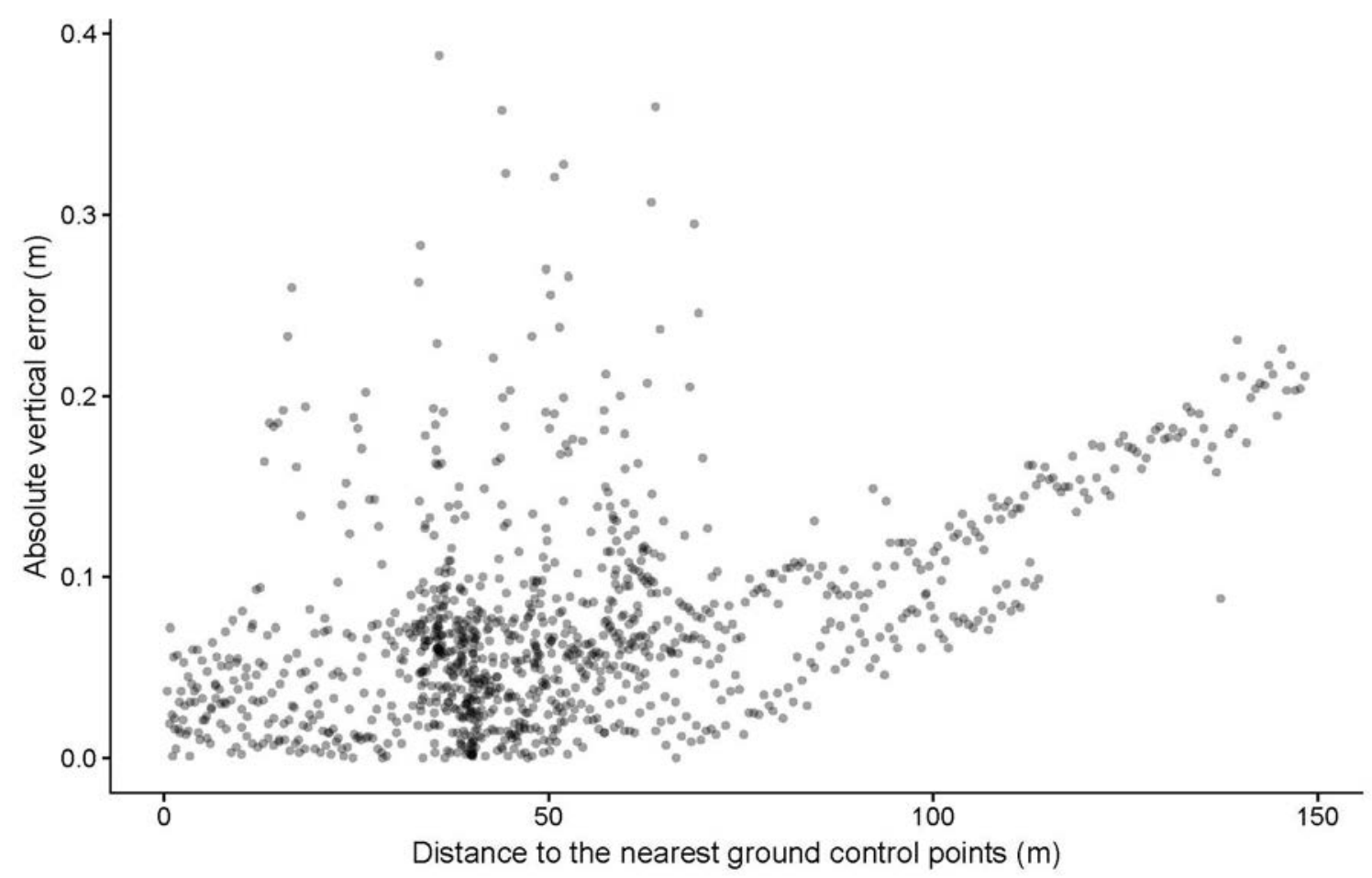

Figure S4.2 The relationship between the distance to the nearest ground control points (m) to the absolute vertical error (m). 


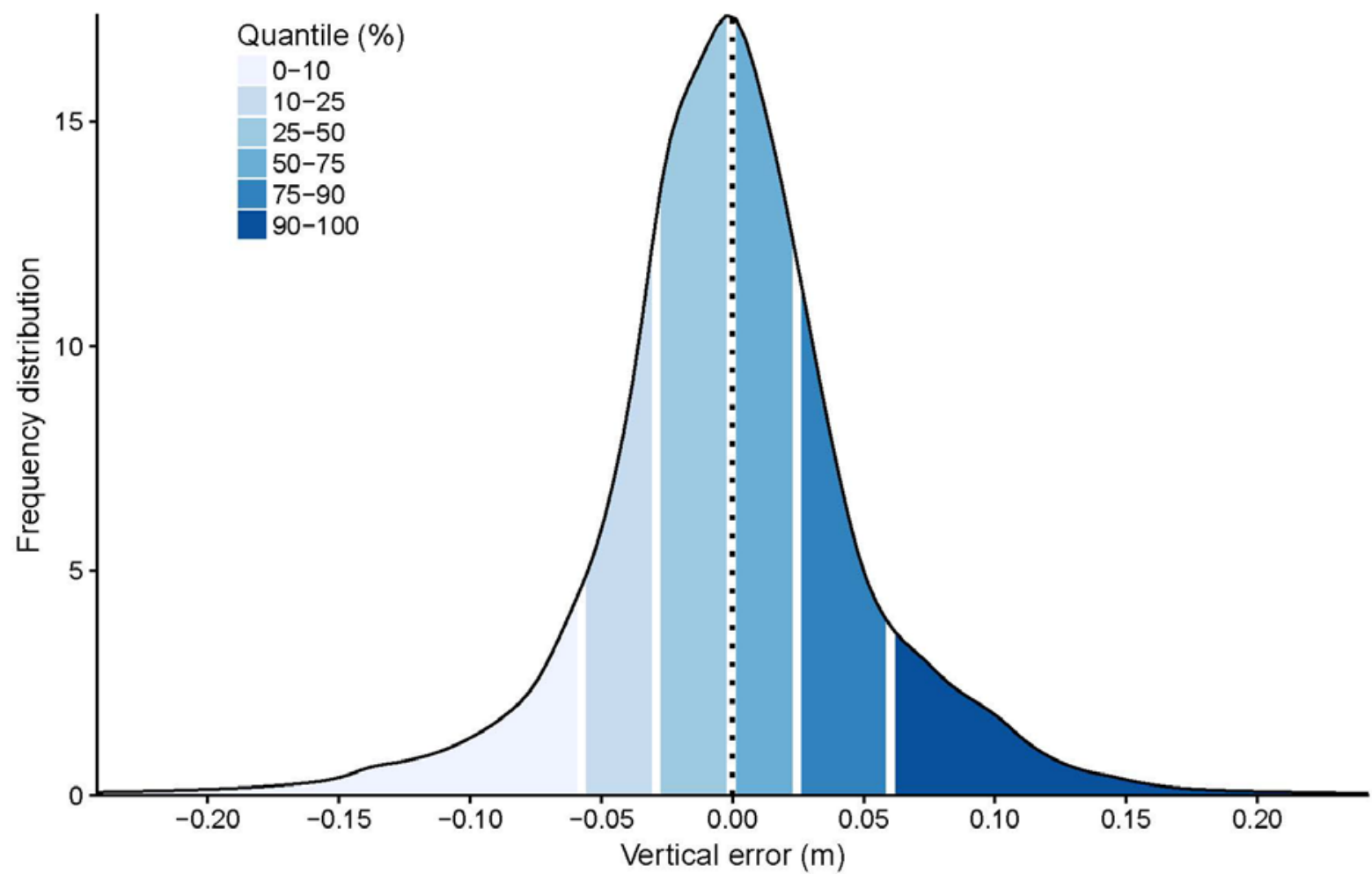

Figure S4.3 The frequency distribution of the vertical difference between repeated flights of the same flight path at the same day. The colours indicate the quantile distribution.

Table S4.1 The deviation of the nebka dune volume for different dune sizes for a vertical error of $10 \mathrm{~cm}$ and $20 \mathrm{~cm}$.

\begin{tabular}{lllll}
\hline Area & $\begin{array}{l}\text { Mean } \\
\text { elevation }\end{array}$ & Volume & $\begin{array}{l}\text { Deviation (\%) } \\
\text { for } 10 \mathrm{~cm} \text { error }\end{array}$ & $\begin{array}{l}\text { Deviation (\%) } \\
\text { for } 20 \mathrm{~cm} \text { error }\end{array}$ \\
\hline 0.51 & 2.83 & 1.45 & 3.57 & 7.10 \\
2.54 & 2.05 & 5.22 & 4.89 & 9.75 \\
5.01 & 2.16 & 10.84 & 4.62 & 9.24 \\
10.18 & 2.48 & 25.26 & 4.03 & 8.06 \\
20.25 & 1.70 & 34.42 & 5.88 & 11.77 \\
50.73 & 2.28 & 115.66 & 4.39 & 8.77 \\
156.30 & 2.21 & 344.85 & 4.53 & 9.07 \\
16967.23 & 3.80 & 64444.20 & 2.63 & 5.27 \\
\hline
\end{tabular}


Table S4.2 Overview of characteristics of optimized dense point clouds obtained with the Structure-from-Motion algorithm applied in the Agisoft Photoscan software for the three different mapping campaigns.

\begin{tabular}{llll}
\hline Mapping campaign & August 2016 & April 2016 & November 2016 \\
\hline Number of alinged camera's & 844 & 827 & 872 \\
Number of points dense point cloud & $71,354,624$ & $77,189,711$ & $75,327,967$ \\
Effective overlap (\%) & 6.1 & 4.9 & 5.1 \\
Estimated mean point density (n m ${ }^{-2}$ ) & 573 & 648 & 612 \\
Mean reprojection error (pixels) & 0.52 & 1.13 & 1.17 \\
Flying altitude (m) & 79.6 & 72.1 & 75 \\
\hline
\end{tabular}

